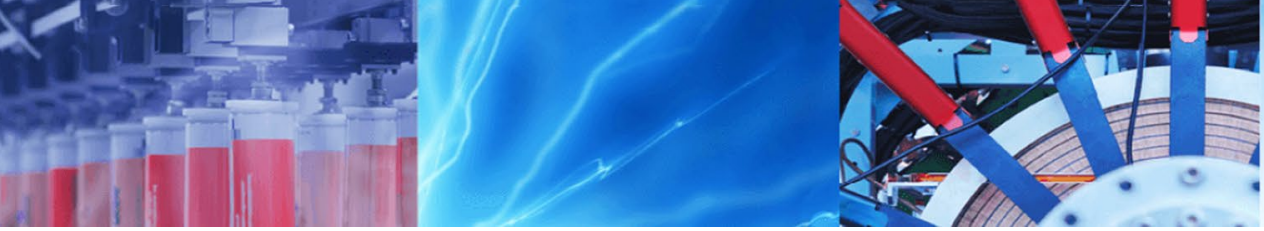

Research Article

\title{
Seasonal variations of size-fractionated chlorophyll $a$ and primary production in the coastal area of Hokkaido in the Okhotsk Sea
}

\author{
Akihiro Shiomoto ${ }^{1} \cdot$ Kosuke Inoue $^{1}$ \\ Received: 29 June 2020 / Accepted: 19 October 2020 / Published online: 24 October 2020 \\ (c) Springer Nature Switzerland AG 2020
}

\begin{abstract}
The size structure of phytoplankton has a significant influence on the marine ecosystem and fishery production. To elucidate which size of phytoplankton make up the majority of the primary producer community, size-fractionated chlorophyll $a$ and primary production were investigated in the coastal area of Hokkaido in the Okhotsk Sea, which has high fishery production. Large ( $>10 \mu \mathrm{m}$ ) phytoplankton accounted for approximately $80 \%$ of biomass and production in the spring bloom, approximately $40-75 \%$ in summer and autumn, but only approximately $20 \%$ in winter. Nutrient limitation possibly led to the lower contributions of large phytoplankton to biomass and production in summer and autumn. The size structure of chlorophyll $a$ reflected that of primary production. Large phytoplankton were considered the main producers throughout the year, except winter. However, there was no significant difference in the chlorophyll $a$-specific primary production among the three sizes (large: $>10 \mu \mathrm{m}$; medium: 2-10 $\mu \mathrm{m}$; small: $<2 \mu \mathrm{m}$ ) in any season, implying the same growth rates in the three sizes. The lower contribution of large phytoplankton in winter may has been due to an intense copepod grazing. Large phytoplankton are likely to be the main primary producers throughout the year, leading to high fishery production in the study area.
\end{abstract}

Keywords Size fractionation · Primary production $\cdot$ Chlorophyll $a \cdot$ Chlorophyll $a$-specific primary production $\cdot$ Large phytoplankton · Coastal area of hokkaido in the okhotsk sea

\section{Introduction}

The size structure of a phytoplankton community influences its food web structure, the ecosystem's biomass and production [1-4], and hence, fishery production. It is well known that the concentration of nutrients in an ecosystem significantly affects the size structure of the phytoplankton community. It has been reported from field surveys that large phytoplankton dominate under nutrient-rich conditions, whereas small phytoplankton dominate under oligotrophic conditions [2,5-12]. The supply of nutrients to the upper layers is also important for controlling the size structure of the phytoplankton community $[9,10$, 13]. Ecosystems dominated by large phytoplankton have fewer trophic levels than those dominated by small ones [3]. When the trophic level increases by one, the biomass becomes one-tenth $[3,14,15]$. Therefore, ecosystems, in which large phytoplankton make up the bulk of main primary producers, can maintain a higher fishery production than that of the systems with small phytoplankton. Accordingly, it is important to determine which phytoplankton size is the main component of the total primary producers.

Our study area is located in the southwestern part of the Okhotsk Sea and has prosperous fisheries [16-18]. In the study area, the Soya Warm Current, a warm current, flows from late spring to late autumn, and the East Sakhalin Current, a cold current, flows from late autumn to spring of the

Akihiro Shiomoto, a3shiomo@nodai.ac.jp | ${ }^{1}$ Faculty of Bioindustry, Tokyo University of Agriculture, 196 Yasaka, Abashiri, Hokkaido 099-2493, Japan. 
following year; moreover, the area is occupied with drift ice during the mid-winter period [19-21]. The changes in the marine environment according to season are remarkably pronounced in this area, and they include variations in environmental factors such as temperature, nutrients, and light, which affect phytoplankton production and biomass [18, 19, 21-26].

According to the summary of Shiomoto et al. [18], the water temperature rises from around $0^{\circ} \mathrm{C}$ in early spring toward summer, reaching a maximum water temperature of around $20^{\circ} \mathrm{C}$. After that water temperature decreases again in the winter. Nutrient concentrations are high in early spring, but become extremely low throughout the phytoplankton spring bloom, remaining low until late autumn and rising again in early winter. For example, nitrate, which is considered to be the limiting nutrient for phytoplankton in spring bloom, decreases from ca. $15 \mu \mathrm{mol} / \mathrm{L}$ to almost depleted condition through the spring bloom and reaches ca. $2 \mu \mathrm{mol} / \mathrm{L}$ in early winter. These remarkable environmental changes should result in marked seasonal changes in primary producers.

A previous study about the size structure of phytoplankton standing stock (chlorophyll $a$ concentration) in this area has been conducted. The spring bloom by diatoms occurs in April, and the chlorophyll a concentration, which is below $1 \mu \mathrm{g} / \mathrm{L}$ in early spring, reaches a maximum of $30 \mu \mathrm{g} / \mathrm{L}$ [18]. After spring bloom, chlorophyll a concentration is around $1 \mu \mathrm{g} / \mathrm{L}$ until winter. Spring blooms are dominated by large $(>10 \mu \mathrm{m})$ phytoplankton, which continues until late autumn. Smaller $(<10 \mu \mathrm{m})$ phytoplankton dominate in winter. However, size-fractionated primary production has not yet been measured. The standing stock of phytoplankton is determined by the difference between production and loss, implying that chlorophyll $a$ size structure does not necessarily reflect the main primary producers. Therefore, to determine which phytoplankton size make up the majority of the primary producer community, we measured the seasonal variations in size-fractionated primary production as well as size-fractionated chlorophyll $a$ in the coastal area of Hokkaido in the Okhotsk Sea.

\section{Materials and methods}

This study was conducted in the coastal area of Hokkaido, Okhotsk Sea, during a cruise of the "Wakashio Maru" of the Abashiri Fishery Cooperative in the period of April-December (avoiding drift ice period) 2011-2015 (Fig. 1). During the 5 year study period, surveys were conducted 4 times in August and December; 5 times in October; 6 times in April, June, and November; 7 times in May; 8 times in September; and 9 times in July. The survey area is a scallop aquaculture ground with water depth of approximately $60 \mathrm{~m}$. Surface water samples were collected at 0800-1200 h using an acid-cleaned plastic bucket. Water temperature and salinity at the surface were measured using a digital thermometer (SN3000, NETSUKEN) and salinometer (Model 5, Tsurumi Seiki), respectively. Nutrient concentrations were measured with a BLTEC Auto Analyzer SWAAT after storing the samples at $-70^{\circ} \mathrm{C}$.

The chlorophyll $a(\mathrm{Chl} a)$ concentrations of total and size-fractionated samples were measured fluorometrically using a Turner Designs 10-AU fluorometer according to Welschmeyer [27]. The water samples $(200 \mathrm{~mL})$

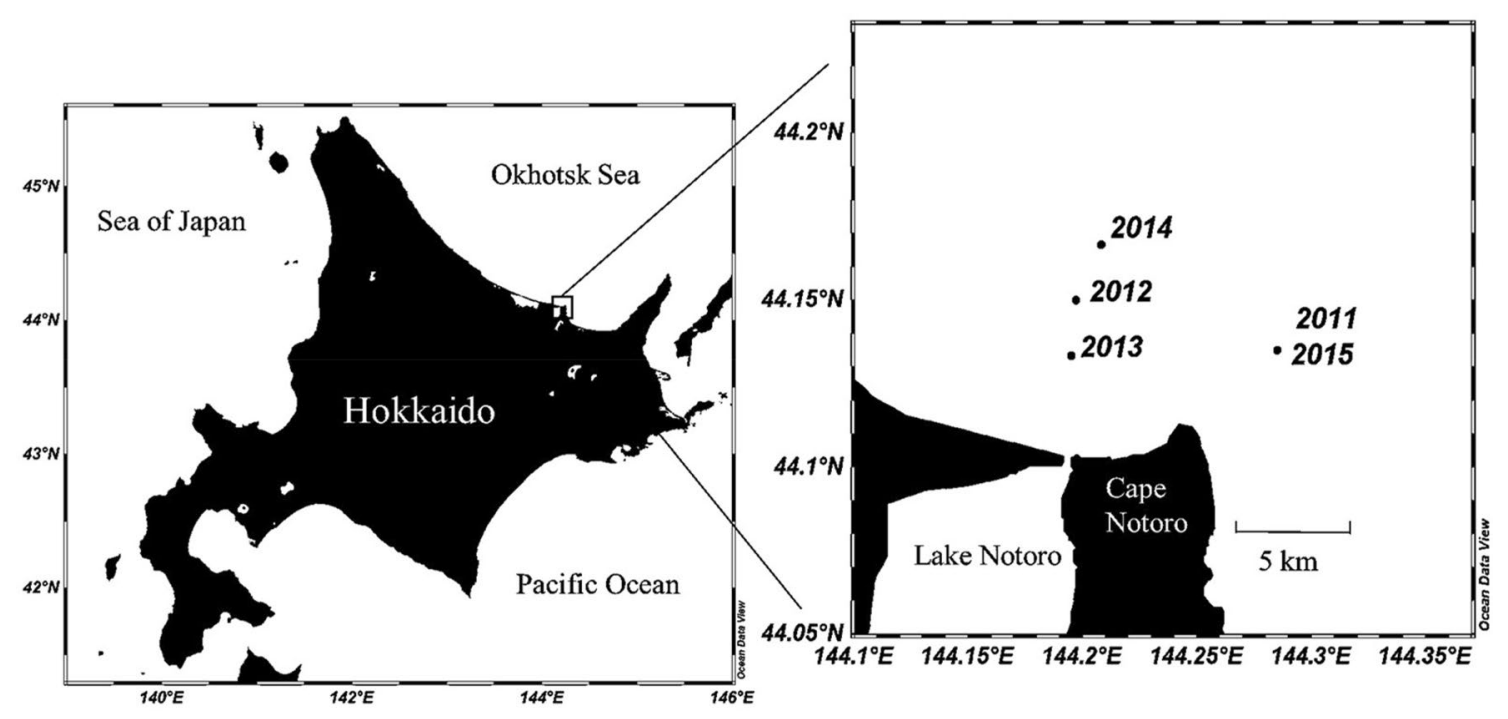

Fig. 1 Location of the sampling stations along the coastal area of Hokkaido in the Okhotsk Sea. The numbers represent the years of each investigation. The water depth of the stations was approximately $60 \mathrm{~m}$ 
were filtered through Nuclepore filters with pore sizes of 10 and $2 \mu \mathrm{m}$, and the filtrate was re-filtered through Whatman GF/F filters (approximately $0.7 \mu \mathrm{m}$ pore size). Size fractions of $<2$ and $<10 \mu \mathrm{m}$ were collected. In addition, $200 \mathrm{~mL}$ water samples were directly filtered using Whatman GF/F filters (total). Chl $a$ was extracted with $\mathrm{N}$, $\mathrm{N}$-dimethylformamide [28]. Calibration of the fluorometer was performed using a commercially available Chla standard (MERK). Chl $a$ concentrations for the $<2-\mu \mathrm{m}$ size fraction (small) and the total sample were obtained directly and those for the 2-10- $\mu$ m (medium) and the $>10-\mu \mathrm{m}$ (large) size fractions were obtained from the differences between the $<10$ and $<2-\mu \mathrm{m}$ size fractions and between the total and $<10-\mu \mathrm{m}$ size fractions, respectively.

Primary production was measured by the simulated in situ method using the ${ }^{13} \mathrm{C}$ uptake technique [29]. The samples $(2 \mathrm{~L}$ ) were dispensed into two 2-L polycarbonate bottles and enriched with ${ }^{13} \mathrm{C}-\mathrm{NaHCO}_{3}$ (98 atom $\%{ }^{13} \mathrm{C}$; Isotec) to approximately $10 \%$ of the total inorganic carbon in ambient water within 3-4 h of sample collection. The samples were placed in a water tank installed on the roof of the Tokyo University of Agriculture building and incubated under sunlight for $24 \mathrm{~h}$ at the same water temperature as that in which the samples were collected. Dark bottle uptake is similar to the zero-time blank in the ${ }^{13} \mathrm{C}$ technique [30], and thus, no dark bottles were not used. Photon fluxes [photosynthetically available radiation (PAR) 400-700 nm] were monitored every $5 \mathrm{~min}$ with a quantum sensor (LI-190R, Li-Cor) during the incubation.

Following incubation, the seawater samples in bottles were immediately supplied to the size-fractionation operation. The procedure used for size-fractionation was the same as that used for Chl $a$. The Whatman GF/F filters used for measuring primary production were pre-combusted at $450{ }^{\circ} \mathrm{C}$ for $4 \mathrm{~h}$. Before the isotope analysis, the filters were treated with $\mathrm{HCl}$ fumes for $4 \mathrm{~h}$ to remove inorganic carbon and completely dried in a vacuum desiccator. The isotopic ratios of ${ }^{13} \mathrm{C}$ to ${ }^{12} \mathrm{C}$ and particulate organic carbon contents were determined using a mass spectrometer (ANCA SL or INTEGRA 2CN, CerCon). The total inorganic carbon in the water was measured using an infrared analyser (TOC 5000, Shimadzu). Primary production was calculated according to the equation described by Hama et al. [29], and the values of the two polycarbonate bottles were averaged. Primary production for the $<2-\mu \mathrm{m}$ (small), 2-10- $\mu \mathrm{m}$ (medium), and $>10-\mu \mathrm{m}$ (large) size fractions were obtained from the same procedure as that for $\mathrm{Chl} a$.

Principal component analysis (PCA) was carried out to investigate how the environmental factors (light, water temperature, salinity, nutrients) are related to the size structure of phytoplankton biomass and production. PCA was performed using Excel Statistics 2012 for Windows ${ }^{\circledR}$
(SSRI Co., Ltd., Japan). Statistical significance was determined at $p<0.05$.

\section{Results}

\subsection{Physical and chemical environments}

Water temperature increased from April-August and decreased from September onward (Fig. 2a). The minimum value of the year was approximately $2^{\circ} \mathrm{C}$ in April, and the maximum value was approximately $20^{\circ} \mathrm{C}$ in August. Water temperatures over $10^{\circ} \mathrm{C}$ were observed between June and October. Salinity was approximately 32.0 in April and May, between 33.0 and 33.5 in June-October, and approximately 31.3 in November and December (Fig. 2b). The influences of the East Sakhalin Current (temperature: $\left\langle 7^{\circ} \mathrm{C}\right.$; salinity: $<32.0$ ] [21] and the Soya Warm Current (temperature: $7-20^{\circ} \mathrm{C}$; salinity: 33.6-33.4) [21] were strongly observed in April-May and June-October, respectively. November and December were again affected by the East Sakhalin Current.

Nitrate concentrations were $2-6 \mu \mathrm{mol} \mathrm{L}^{-1}$ in April, May, November, and December, and approximately $0.3 \mu \mathrm{mol}$ $\mathrm{L}^{-1}$ in June-October (Fig. 2c). Nitrate concentrations were relatively high from early winter to the next spring, influenced by the East Sakhalin Current, and were nearly depleted from early summer to late autumn because of the Soya Warm Current. The PAR during incubation was approximately $23 \mathrm{~mol}$ photons $\mathrm{m}^{-2} \mathrm{~d}^{-1}$ in April and May, 12-28 mol photons $\mathrm{m}^{-2} \mathrm{~d}^{-1}$ in June-October, and approximately 5 mol photons $\mathrm{m}^{-2} \mathrm{~d}^{-1}$ in November and December (Fig. 2d); the PAR was significantly lower in winter compared to the other seasons.

\subsection{Chlorohyll $a$}

The maximum mean value of total $\mathrm{Chl} a$ throughout the year was $5.0 \mathrm{mg} \mathrm{m}^{-3}$ in April (Fig. 3a). The maximum value measured over the five years was $8.4 \mathrm{mg} \mathrm{m}^{-3}$ on April 1, 2015. These observations indicate that the spring bloom in the survey area occurred in April. From May-December, the monthly mean values were between 0.7 and $2 \mathrm{mg} \mathrm{m}^{-3}$. There were no significant differences among the total $\mathrm{Chl} a$ concentrations in each month, except for in April (Kruskal-Wallis test, $p>0.05$ ).

Large $(>10 \mu \mathrm{m})$ phytoplankton were dominant in April, accounting for $84 \%$ of the total $\mathrm{Chl} a$ concentration (Fig. 3b). They were also dominant between May and October, but the proportion was lower (42-74\%). In November and December, the proportions of medium and small phytoplankton were high, at approximately $35 \%$ and $45 \%$, respectively. Combined, both size classes accounted for 

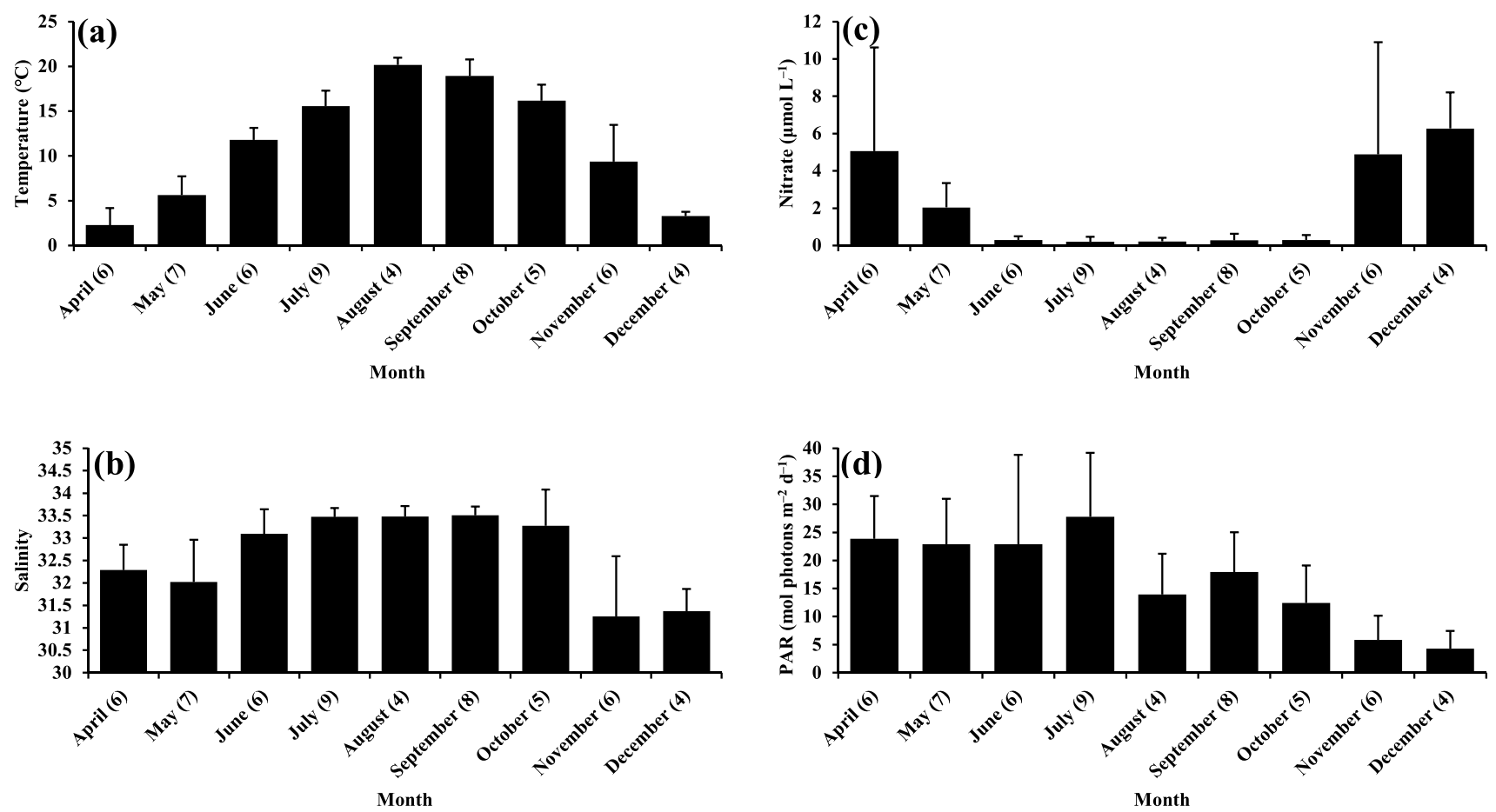

Fig. 2 Seasonal variations in the mean and standard deviation of the temperature $\mathbf{a}$, salinity $\mathbf{b}$, nitrate $\mathbf{c}$, and photosynthetically available radiation (PAR) during incubation $\mathbf{d}$. The mean values and

standard deviations for each month were calculated using all data obtained in the 5-year study. The numbers in parentheses represent the number of data sets

approximately $80 \%$ of the total phytoplankton. The proportion of large phytoplankton was low, accounting for approximately $20 \%$.

\subsection{Primary production}

The maximum mean value of total primary production throughout the year was found in April, similar to the total $\mathrm{Chl} a$ concentration, and it was $62 \mathrm{mg} \mathrm{C} \mathrm{m}^{-3} \mathrm{~d}^{-1}$ (Fig. 4a). The maximum value measured over the five years was $123 \mathrm{mg} \mathrm{C} \mathrm{m}^{-3} \mathrm{~d}^{-1}$ on April 1, 2015. These results support the occurrence of the spring bloom in April. From May-November, the mean values were of $20-45 \mathrm{mg} \mathrm{C}$ $\mathrm{m}^{-3} \mathrm{~d}^{-1}$; the value in December was approximately $6 \mathrm{mg}$ $\mathrm{C} \mathrm{m}^{-3} \mathrm{~d}^{-1}$, which was less than one-third of the mean values of the other months. There was no significant difference in the primary production from May to November (Kruskal-Wallis test, $p>0.05$ ), whereas a significant difference was obtained by including the results for December (Kruskal-Wallis test, $p<0.05$ ). The seasonal variation in total primary production was the same as that for the total $\mathrm{Chl} a$ concentration, except for the low value in December.

Large phytoplankton were dominant in terms of the total primary production in April, accounting for $82 \%$ (Fig. 4b). They were also dominant from May-October, but the proportion was 48 to $66 \%$. In November and
December, the proportions of medium and small phyoplankton were high, accounting for $52 \%$ and $35 \%$ in November and $41 \%$ and $31 \%$ in December, respectively. Both sizes accounted for approximately $80 \%$ of the average for November and December. The proportion of large phytoplankton was low, accounting for $13 \%$ in November and $28 \%$ in December. The seasonal variation in the size structure of primary production was the same as that of the total Chl $a$ concentration, showing that the size structure of $\mathrm{Chl} a$ reflected that of primary production.

\subsection{Chlorophyll $a$-specific primary production}

Primary production is affected not only by light but also by phytoplankton biomass. The light-saturated production divided by $\mathrm{Chl}$ a concentration is called the assimilation number, which represents the maximum specific growth rate $[31,32]$. Since there was no guarantee that the primary production obtained in this study was lightsaturated, the primary production divided by $\mathrm{Chl} a$ concentration is herein referred as the $\mathrm{Chl} a$-specific primary production, considered an index of the specific growth rate. The values of $\mathrm{Chl} a$-specific primary production were higher for all phytoplankton sizes from June-October (summer and autumn) and lower in April and May (spring) and November and December (winter) (Fig. 5). For all sizes, 
Fig. 3 Seasonal variations in the mean and standard deviation of the total chlorophyll $a$ concentration $\mathbf{a}$ and the mean size structure of chlorophyll $a$ concentration $\mathbf{b}$. The mean values and standard deviations for each month were calculated using all data obtained in the 5-year study. The numbers in parentheses represent the number of data sets
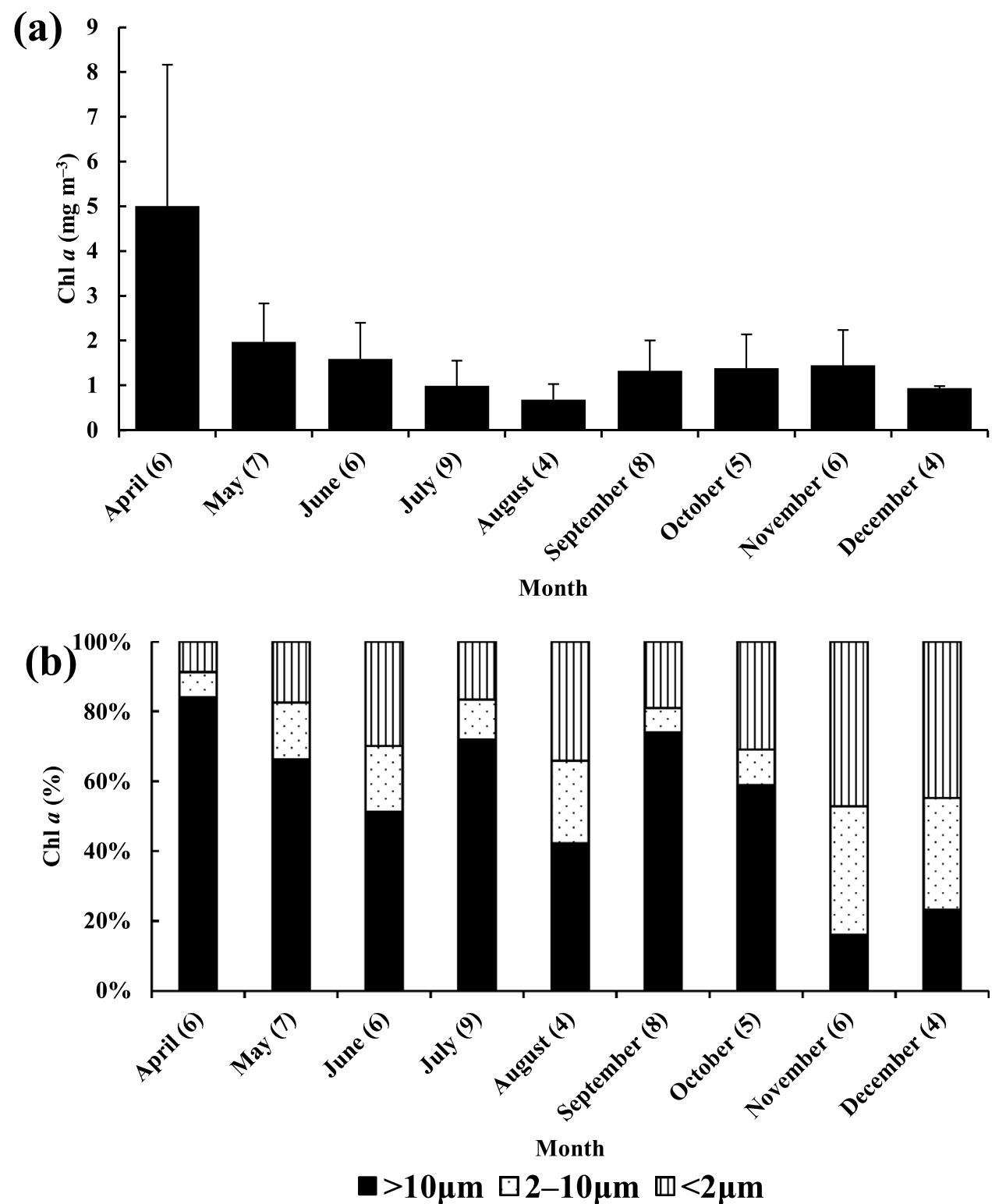

the values of $\mathrm{Chl} a$-speific primary production were significantly higher in summer and autumn than in spring and winter (Mann-Whitney $U$ test, $p<0.05$ ). There was no significant difference in the values between spring and winter for medium and small phytoplankton (Mann-Whitney $U$ test, $p>0.05$ ); however, for large phytoplankton, the $\mathrm{Chl}$ $a$-specific primary production was significantly higher in spring than in winter (Mann-Whitney $\mathrm{U}$ test, $p<0.05$ ). Higher values were found in the Soya Warm Current water, whereas the lower values were found in the East Sakhalin Current water.

There were no significant differences in the $\mathrm{Chl} a$-specific primary prduction among the three sizes in all seasons (April-December), spring (April and May), summer and autumn (June-October), and winter (November and December) (Kruskal-Wallis test, $p>0.05$; Fig. 6a, b, c, d).
However, the average values and the median of the $\mathrm{Chl}$ $a$-specific primary production were the highest in the medium phytoplankton (Fig. 6).

\subsection{Relationship between phytoplankton size structure and environmental factors}

The PCA ordination for 14 variables explained $73.8 \%$ of data variability in the first two axes (Fig. 7). From the PCA ordination diagram (Fig. 7), the first principal component was found to have positive correlations with the nutrients and the percentage contributions of small and medium phytoplankton to $\mathrm{Chl} a$ and primary production. In contrast, negative correlations were found with light, water temperature, salinity, and the percentage contributions of large phytoplankton to $\mathrm{Chl} a$ and primary 
Fig. 4 Seasonal variations in the mean and standard deviation of the total primary production $\mathbf{a}$ and the mean size structure of primary production $\mathbf{b}$. The mean values and standard deviations for each month were calculated using all data obtained in the 5 -year study. The numbers in parentheses represent the number of data sets
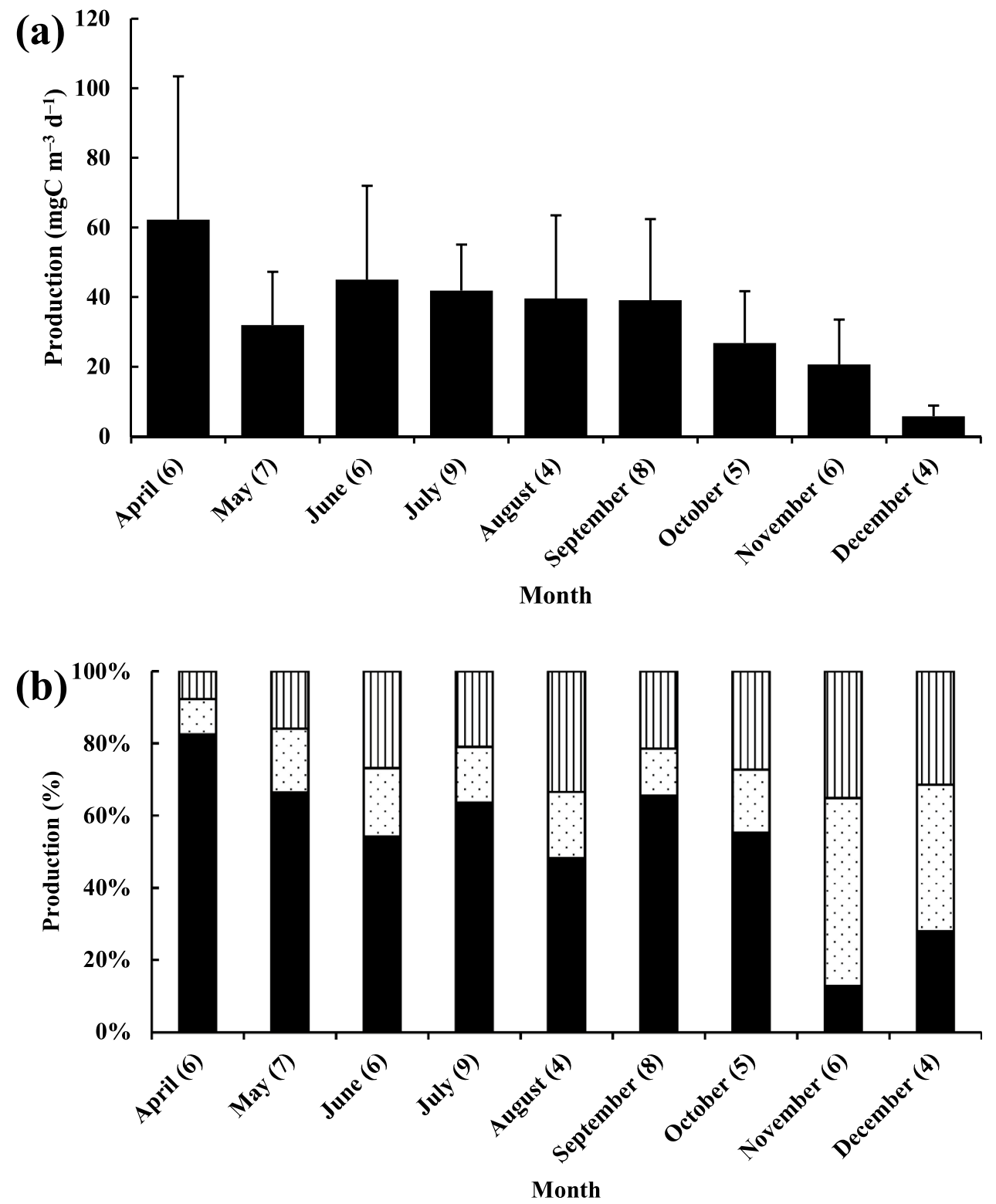

$>10 \mu \mathrm{m} \square 2-10 \mu \mathrm{m} \square<2 \mu \mathrm{m}$ production. These facts indicate that water mass change between warm water (the Soya Warm Current water) and cold water (the Eastern Sakhalin Current water) in the survey area is the first principal component. In relation to the second principal component, positive correlations were found with light, nutrients, and the percentage contributions of large phytoplankton to $\mathrm{Chl} a$ and primary production. Negative correlations were found with water temperature, salinity, and the percentage contributions of small and medium phytoplankton to $\mathrm{Chl}$ $a$ and primary production. These show that the spring bloom is the second principal component.

\section{Discussion}

This study was performed using only surface samples. There is no guarantee that the seasonal changes of $\mathrm{Chl}$ $a$ and primary production at the surface reflect those in the entire water column; accordingly, it is necessary to confirm this. According to Shiomoto et al. [18], a survey of $\mathrm{Chl} a$ in the entire water column showed high values $(10-30 \mu \mathrm{g} / \mathrm{L})$ in the spring bloom (April), followed by low values (ca. $1 \mu \mathrm{g} / \mathrm{L})$ up to December. In the size structure of $\mathrm{Chl} a$, large phytoplankton occupied a high proportion 
Fig. 5 Seasonal variations in the mean and standard deviation of the chlorophyll $a$-specific primary production ( $\mathrm{mgC}$ $\left.\mathrm{mgChl} a^{-1} \mathrm{~d}^{-1}\right)$ of the large

$(>10 \mu \mathrm{m}) \mathbf{a}$, medium $(2-10 \mu \mathrm{m})$ b, and small $(<2 \mu \mathrm{m})$ c phytoplankton. The mean values and standard deviations for each month were calculated using all data obtained in the 5-year study. The numbers in parentheses represent the number of data sets
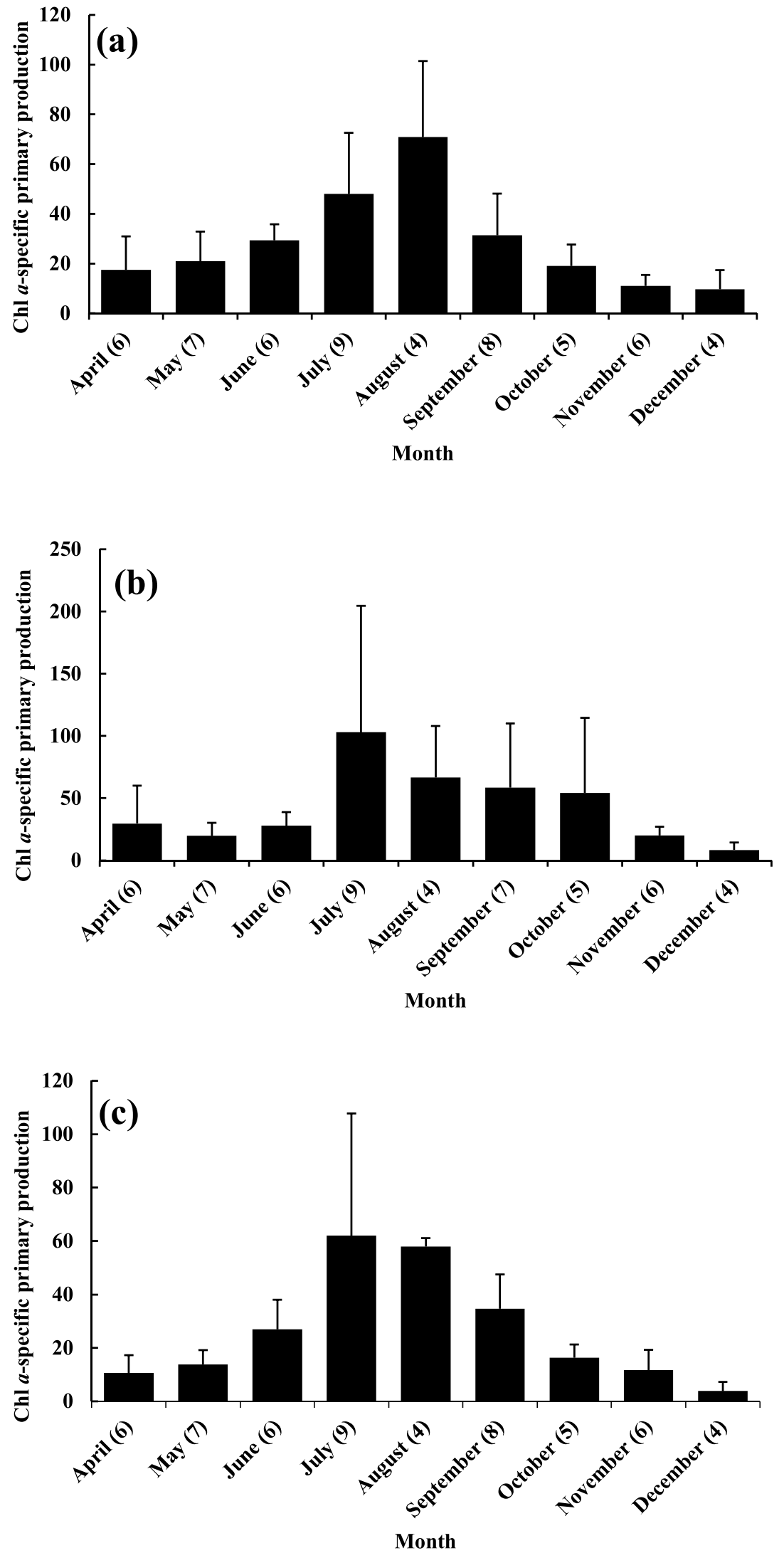

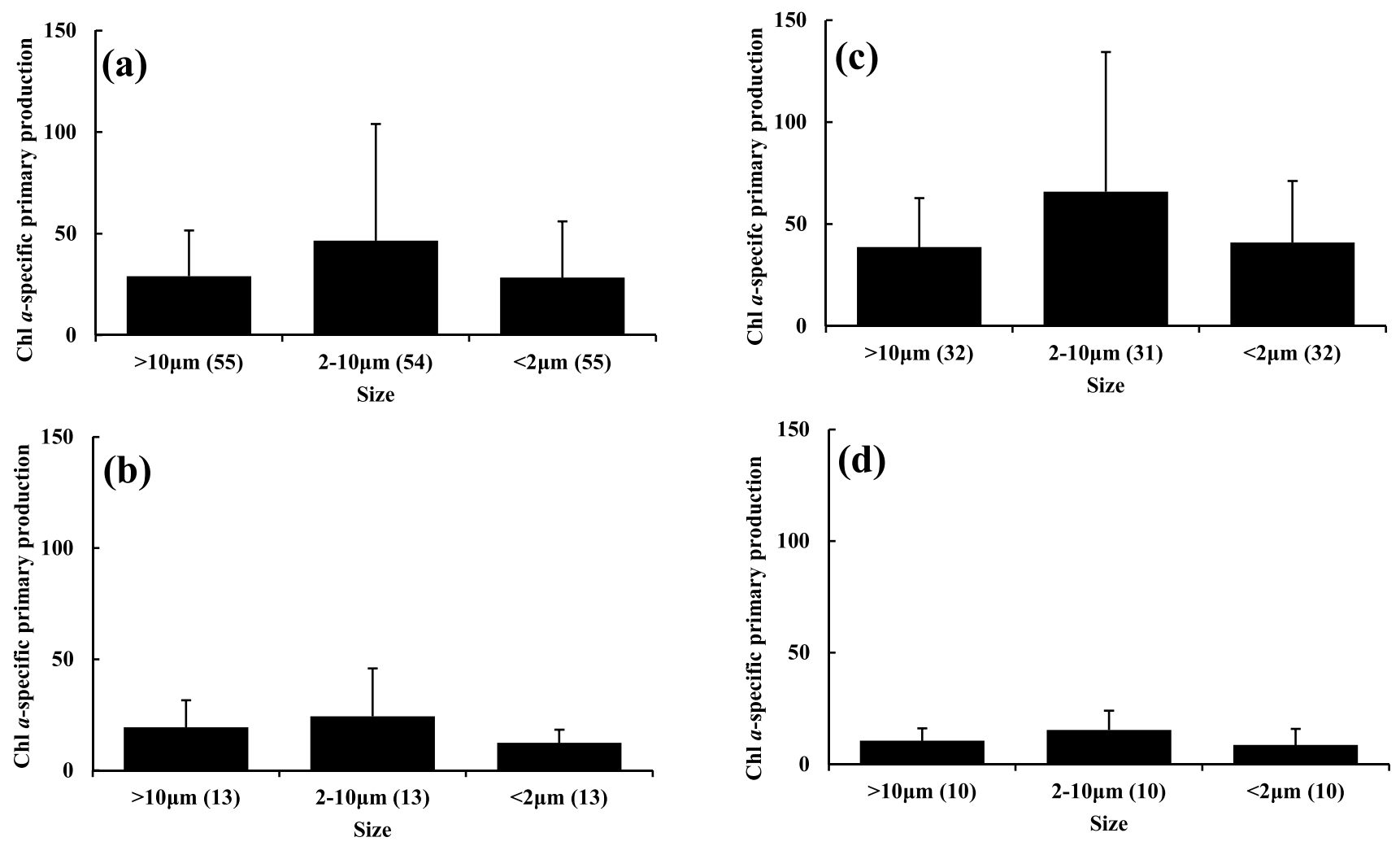

Fig. 6 Comparison of the mean and standard deviation of the chlorophyll $a$-specific primary production ( $\mathrm{mgC} \mathrm{mgChl} a^{-1} \mathrm{~d}^{-1}$ ) among large $(>10 \mu \mathrm{m})$, medium $(2-10 \mu \mathrm{m})$, and small $(<2 \mu \mathrm{m})$ phytoplankton in all seasons (April-December) a, spring (April and May) b,

summer and autumn (June-October) c, and winter (November and December) $\mathbf{d}$. The numbers in parentheses represent the number of data sets

Fig. 7 Principal components analysis (PCA) ordination diagram for the percentage contributions of large $(>10 \mu \mathrm{m})$, medium $(2-10 \mu \mathrm{m})$, and small $(<2 \mu \mathrm{m})$ phytoplankton to $\mathrm{Chl}$ $a$ and primary production, and environmental factors (light, water temperature, salinity, and nutrients). PAR: light; T: water temperature; S: salinity; Chl: chlorophyll $a$; P: primary production

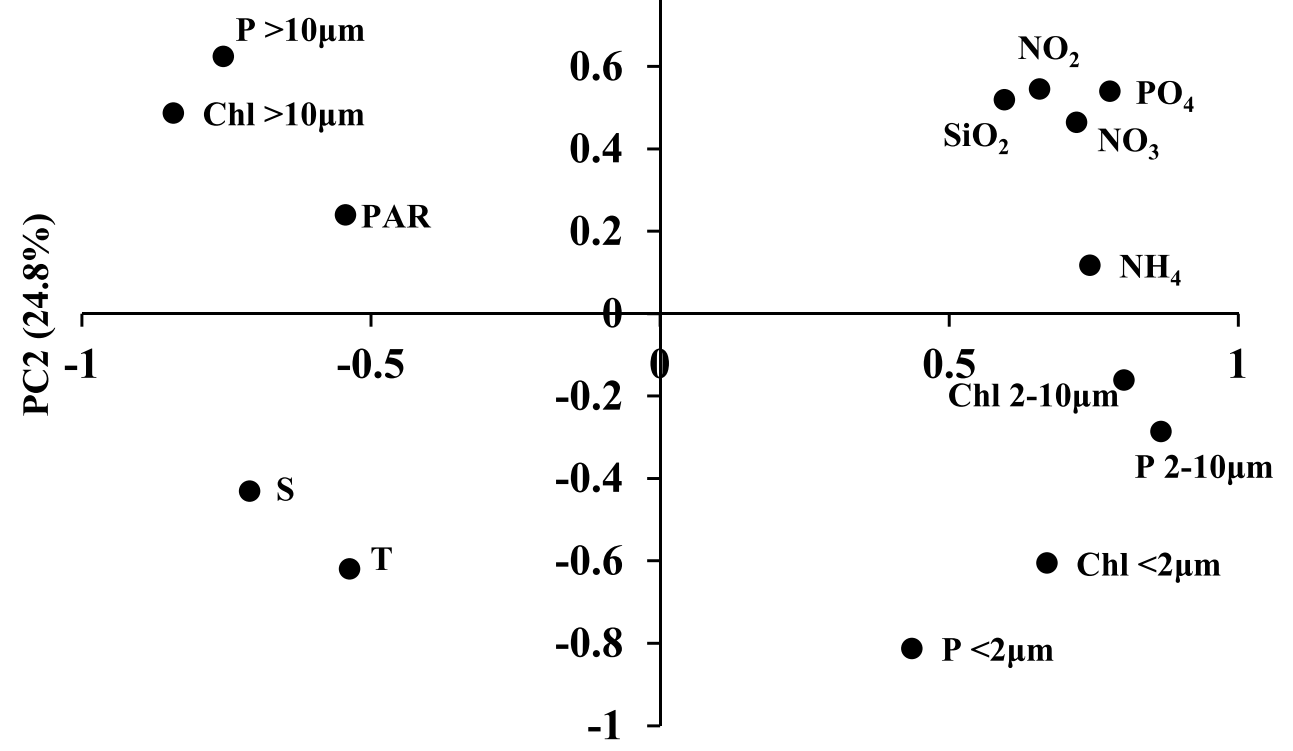

PC1 $(49.0 \%)$ 
in spring (ca. 70\%) and also a relatively high proportion (ca. 40-70\%) until late autumn. On the other hand, in winter, smaller phytoplankton $(<10 \mu \mathrm{m})$ accounted for a high proportion (ca. $75 \%$ ). These results were in good agreement with the results seen in this study (Fig. 3). The seasonal variation of $\mathrm{Chl} a$ at the surface likely reflects that of the entire water column. This study also showed that seasonal variations in $\mathrm{Chl} a$ and primary production were in good agreement, showing that surface primary production may have reflected that of the entire water column.

There was no significant difference in the $\mathrm{Chl} a$-specific primary production, an index of the growth rate, among the three sizes in any season (Fig. 6). Chl $a$-specific primary production and growth rate have been reported to be higher for small phytoplankton [33-37], but recent studies have pointed out that these values are highest for medium phytoplankton $(6-10 \mu \mathrm{m})$ [38-40]. Moreover, no significant difference in $\mathrm{Chl} a$-specific primary production was found among the different phytoplankton sizes in the subarctic region (water temperature: $<10^{\circ} \mathrm{C}$ ) [41-43]. In the polar region, the difference in productivity was small between sizes [44]. The results of the present study showed that the $\mathrm{Chl} a$-specific primary production was not significantly different among the three sizes in winter and spring when the water temperature was $<10^{\circ} \mathrm{C}$, which is consistent with previous findings [41-44]. Moreover, in summer and autumn, when the water temperature was $10-20^{\circ} \mathrm{C}$, no significant difference in the value was observed among the three sizes. No significant difference can be found among sizes throughout the year in the subarctic region, even at the high summer temperatures. In the subarctic region, further studies are needed to determine whether the $\mathrm{Chl} a$-specific primary production varies among sizes.

The same $\mathrm{Chl} a$-specific primary production implies that the growth rates are the same for all sizes. The larger the phytoplankton, the higher the carbon content per cell [45-47]. If nutrient concentration is sufficient for large phytoplankton and there are no losses from grazing or sedimentation [48, 49], large phytoplankton should dominate; this was observed in spring, summer, and autumn but not in winter (Figs. 3b, 4b), indicating that there may be severe limitations and many losses in winter but not in spring, summer, and autumn. Before the spring bloom, there was a high-nutrient condition (Fig. 2c). The lower respiratory loss resulting from the shallower mixed layer is considered to cause the spring bloom in the study area [18]. Kitamura et al. [50] and Nakagawa et al. [51] reported that copepods, which feed on large phytoplankton (e.g., [49]), are not abundant in spring bloom in this area. It is probable that there were no severe limitations or many losses in the spring bloom, and hence the spring bloom of the large phytoplankton occurred even though the $\mathrm{Chl} a$-specific primary production was lower than that in summer and autumn (Fig. 5).

This study showed that the change of water mass plays a significant role in the seasonal variation of the size structure of phytoplankton biomass and production in the study area (Fig. 7). Changes of water mass were observed in the early summer and early winter. We therefore discuss which phytoplankton size make up the largest proportion of the primary producers in summer and autumn and winter. In summer and autumn, large phytoplankton were main primary producers in the study area based on the results of $\mathrm{Chl} a$ (Fig. 3b) and primary production (Fig. 4b). Conversely, the nutrient concentrations were remarkably lower in summer and autumn (Fig. 2c). The findings on the relationship between the nutrient condition and phytoplankton size structure have shown that small phytoplankton dominate under nutrient-poor conditions, and large phytoplankton dominate under relatively highnutrient conditions, regardless of the ocean type (open sea or coastal) [2, 5-12]. The result of this study, in which large phytoplankton dominated despite remarkably low nutrient concentrations, is contrary to the previous findings about the relationship between nutrient concentration and phytoplankton size structure. In other words, a paradox was found in summer and autumn.

In summer and autumn, $\mathrm{Chl} a$ concentrations of large phytoplankton were of $0.04-2.38 \mathrm{mg} \mathrm{m}^{-3}$, and the frequency of observations of $>1 \mathrm{mg} \mathrm{m}^{-3}$ of $\mathrm{Chl} a$ for large phytoplankton was approximately $25 \%$ in all observations. Values $>1 \mathrm{mg} \mathrm{m}^{-3}$ are found when $>1 \mu \mathrm{mol} \mathrm{L}{ }^{-1}$ of nitrate is available in the open sea [12]. All of nitrate concentrations were less than $1 \mu \mathrm{mol} \mathrm{L^{-1 }}$ in summer and autumn (Fig. 2c). These facts imply a nitrate supply from somewhere. However, the $\mathrm{Chl} a$ concentration and primary production were lower in summer and autumn than in the spring bloom (Figs. 3a, 4a). Furthermore, the percentage contribution of large phytoplankton to $\mathrm{Chl}$ $a$ and primary production were $40-75 \%$ (Figs. 3b, 4b), which was lower than the contribution (approximately $80 \%$ ) in the spring bloom. The lower $\mathrm{Chl} a$ concentration and primary production contributions in summer and autumn possibly reflected the limiting nutrient (nitrate). In contrast, the possible sources of nitrate remain unconfirmed. The cold belt, characterized by a lower temperature than that of its surroundings, is formed off the Soya Warm Current resulting from the flow of the current during summer and autumn, and it is the driver for upwelling of the lower water (e.g., [52-54]). Therefore, the cold belt is considered an important nutrient (nitrate) source for the study area, as pointed out by Mustapha et al. [55]. Accordingly, the flow of the Soya Warm Current along the coastal area of Hokkaido possibly played an important role in producing the dominance of large 
phytoplankton (diatoms) in summer and autumn. An additional nutrient load may be the intrusion of intermediate cold water from the Okhotsk Sea [18, 25]. Finding a source of nutrient and estimating its supply are the first step to clarify the paradox in summer and autumn.

In winter, the smaller (medium and small) phytoplankton were considered the main primary producers based on the results of $\mathrm{Chl} a$ (Fig. $3 \mathrm{~b}$ ) and primary production (Fig. 4b). However, the nutrient concentration was relatively high in winter (Fig. 2C). A paradox, opposite to that in summer and autumn, was also found in winter. As in other seasons, no significant difference was found in the $\mathrm{Chl} a$-specific primary production among the three sizes in winter (Fig. 6). Accordingly, there should have been many losses for large phytoplankton. Copepods were reported to be relatively abundant in winter $[50,51]$, which implies that there was a greater grazing loss by copepods on large phytoplankton in winter. However, it is well known that grazing by copepods is more significantly reduced than phytoplankton growth at low temperature, e.g., in winter [56].

In the survey area during the ice-free period, Nakagawa et al. [57] showed that grazing by copepods depends on the $\mathrm{Chl}$ a concentration of large phytoplankton; no relationship was found between grazing pressure and water temperature $\left(2-12^{\circ} \mathrm{C}\right)$ in their study. It is thus possible that the grazing impact by copepods on large phytoplankton produces the dominance of the smaller phytoplankton in winter. Furthermore, in Funka Bay, a coastal area of Hokkaido, the grazing pressure of small zooplankton was reported to be low in winter [58]. Although there is no information on grazing by small zooplankton in the study area, the $\mathrm{Chl} a$ concentrations of medium and small phytoplankton were relatively high in winter (mean $\pm S D, n=10 ; 0.44 \pm 0.24 \mathrm{mg} \mathrm{m}^{-3}$ and $0.58 \pm 0.44 \mathrm{mg} \mathrm{m}^{-3}$ for medium and small phytoplankton, respectively) than in other seasons (mean $\pm S D$, $n=45 ; 0.21 \pm 0.18 \mathrm{mg} \mathrm{m}^{-3}$ and $0.32 \pm 0.17 \mathrm{mg} \mathrm{m}^{-3}$ for medium and small phytoplankton, respectively), which suggests the possibility of low grazing impact by small zooplankton on smaller phytoplankton. Apparently, in winter, although the smaller $(<10 \mu \mathrm{m})$ phytoplankton significantly contributed to standing stock and primary production of phytoplankton communities (Figs. 3b, 4b), large phytoplankton might actually be the main primary producers supporting the ecosystem. If this is correct, having large phytoplankton as the main primary producers throughout the year can be said to be one of the mechanisms that support the high fishery production in this area. It is necessary to clarify whether the high grazing of copepods causes the low contribution of large phytoplankton to phytoplankton community.

\section{Conclusion}

Large phytoplankton made up the highest proportion of primary producers in spring, and this was also seen in summer and autumn. Conversely, in winter, smaller (medium and small) phytoplankton were the main primary producers, which is considered an apparent phenomenon when compared to previously reported studies. Based on these observations, we can infer that large phytoplankton are the main primary producers throughout the year. This is a positive finding for elucidating the mechanism leading high fishery production in the study area because generally, and high fishery production is expected when large phytoplankton are the main primary producers.

Acknowledgements We would like to thank the Abashiri Fishery Cooperative for their help in sample collection. This research was supported by funding from the Strategic Research Program of the NODAI Research Institute.

\section{Compliance with ethical standards}

Conflict of interest The authors declare that they have no conflict of interest.

\section{References}

1. Finkel ZV, Beardall J, Flynn KJ, Quigg A, Rees TAV, Raven JA (2010) Phytoplankton in a changing world: cell size and elemental stoichiometry. J Plankton Res 32:119-137. https://doi.org/10.1093/ plankt/fbp098

2. Hilligsøe KM, Richardson K, Bendtsen J, Sørensen LL, Nielsen TG, Lyngsgaard MM (2011) Linking phytoplankton community size composition with temperature, plankton food web structure and sea-air $\mathrm{CO}_{2}$ flux. Deep-Sea Res I 58:826-838. https:// doi.org/10.1016/j.dsr.2011.06004

3. Lalli CM, Parsons TR (1993) Biological Oceanography: An Introduction. Butterworth-Heinemann, Oxford, p 301

4. Legendre L, Rassoulzadegan F (1996) Food-web mediated export of biogenic carbon in oceans: hydrodynamic control. Mar Ecol Prog Ser 145:179-193. https://doi.org/10.3354/meps1 45179

5. Acevedo-Trejos E, Brandt G, Bruggeman J, Merico A (2015) Mechanisms shaping size structure and functional diversity of phytoplankton communities in the ocean. Sci Rep 5:8918. https ://doi.org/10.1038/srep08918

6. Hashimoto S, Shiomoto A (2002) Regional distribution of sizefractionated chlorophyll $a$ concentration at sea surface water adjacent to Japan in May-June 2000. Bull Jpn Soc Fish Oceanogr 66:148-154 (in Japanese with English abstract)

7. Maguer JF, L'Helguen S, Waeles M, Morin P, Riso R, Caradec J (2009) Size-fractionated phytoplankton biomass and nitrogen uptake in response to high nutrient load in the North Biscay Bay in spring. Continental Shelf Res 29:1103-1110. https://doi. org/10.1016/j.csr.200811.012

8. Maita Y, Odate T (1988) Seasonal changes in size-fractionated primary production and nutrient concentrations in the 
temperate neritic water of Funka Bay, Japan. J Oceanogr Soc Japan 44:268-279. https://doi.org/10.1007/BF02302569

9. Marañón E (2015) Cell size as a key determinant of phytoplankton metabolism and community structure. Annu Rev Mar Sci 7:241-264. https://doi.org/10.1146/annurev-marine-01081 4-015955

10. Marañón $E$, Cermeño $P$, Latasa $M$, Tadonléké RD (2015) Resource supply alone explains the variability of marine phytoplankton size structure. Limnol Oceanogr 60:1848-1854. https://doi. org/10.1002/Ino.10138

11. Marañón E, Holligan PM, Barciela R, González N, Mouriño B, Pazó MJ, Varela M (2001) Patterns of phytoplankton size structure and productivity in contrasting open-ocean environments. Mar Ecol Prog Ser 216:43-56. https://doi.org/10.1002/Ino.10138

12. Mousing EA, Richardson K, Ellegaard M (2018) Global patterns in phytoplankton biomass and community size structure in relation to macronutrients in the open sea. Limnol Oceanogr 63:1298-1312. https://doi.org/10.1002/Ino.10772

13. Shiomoto A (1997) Size-fractionated chlorophyll a concentration and primary production in the Okhotsk Sea in October and November 1993, with special reference to the influence of dichothermal water. J Oceanogr 53:601-610

14. Pauly D, Christensen V (1995) Primary production required to sustain global fisheries. Nature 374:255-257. https://doi. org/10.1038/374255a0

15. Ryther JH (1969) Photosynthesis and fish production in the sea. Science 166:72-76. https://doi.org/10.1126/cience.166.3901.72

16. Kim ST (2012) A review of the Sea of Okhotsk ecosystem response to the climate with special emphasis on fish populations. ICES J Mar Sci 69:1123-1133. https://doi.org/10.1093/ iesjms/fss 107

17. Shimada H, Sawada M, Tanaka I, Asami H, Fukamachi Y (2012) A method for predicting the occurrence of paralytic shellfish poisoning along the coast of Hokkaido in the Okhotsk Sea in summer. Fish Sci 78:865-877. https://doi.org/10.1007/s1256 2-012-0513-

18. Shiomoto A, Fujimoto $Y$, Mimura N, Sasaki A, Itoi D, Imasato $S$, Takahashi N, Takenaka Y, Fujita T (2018) Seasonal variations of chlorophyll $a$ and environmental factors in the coastal area of the Okhotsk Sea, Hokkaido. Nippon Suisan Gakkaishi 84:241253 (in Japanese with English abstract)

19. Aota M (1985) II Physics, Chapter 1 Coastal region of the Okhotsk Sea. In: Oceanographic Society of Japan (ed.) Coastal Oceanography of Japanese Islands. Tokai University Press, Tokyo, pp 7-22 (in Japanese)

20. Itoh M, Ohshima KI (2000) Seasonal variations of water masses and sea level in the southwestern part of the Okhotsk Sea. J Oceanogr 56:643-654. https://doi.org/10.1023/A:101112163

21. Takizawa T (1982) Characteristics of the Soya Warm Current. J Oceanogr Soc Japan 38:281-292. https://doi.org/10.1007/BF021 14532

22. Kasai H, Hirakawa K (2015) Seasonal changes of primary production in the southwestern Okhotsk Sea off Hokkaido, Japan during the ice-free period. Plankt Benthos Res 10:178-186. https ://doi.org/10.3800/pbr.10.178

23. Kasai H, Nagata R, Murai K, Katakura S, Tateyama K, Hamaoka S (2017) Seasonal change in oceanographic environments and the influence of interannual variation in the timing of sea-ice retreat on chlorophyll $a$ concentration in the coastal water of northeastern Hokkaido along the Okhotsk Sea. Bull Coast Oceanogr 54:181-192 (in Japanese with English abstract)

24. Kasai H, Nakano Y, Ono T, Tsuda A (2010) Seasonal change of oceanographic conditions and chlorophyll $a$ vertical distribution in the southwestern Okhotsk Sea during the non-iced season. J Oceanogr 66:13-26. https://doi.org/10.1007/s1087 2-010-0002-3
25. Kudo I, Frolan A, Takata H, Kobayashi N (2011) Oceanographic structure and biological productivity in the coastal area of Okhotsk Sea. Bull Coast Oceanogr 49:13-21 (in Japanese with English abstract)

26. Yanada M, Shiga N, Miyake H (2001) Distribution and characteristics of nutrients in the coastal regions of the southern Okhotsk Sea in winter. Umi to Sora 77:1-8 (in Japanese with English abstract)

27. Welschmeyer NA (1994) Fluorometric analysis of chlorophyll $\mathrm{a}$ in the presence of chlorophyll $\mathrm{b}$ and pheopigments. Limnol Oceanogr 39:1985-1992. https://doi.org/10.4319/ lo.1994.39.8.1985

28. Suzuki R, Ishimaru T (1990) An improved method for the determination of phytoplankton chlorophyll using N, N-dimethylformamide. J Oceanogr Soc Japan 46:190-194. https://doi. org/10.1007/BF02125580

29. Hama T, Miyazaki T, Ogawa Y, Iwakuma T, Takahashi M, Otsuki A, Ichimura S (1983) Measurement of photosynthetic production of a marine phytoplankton population using a stable ${ }^{13} \mathrm{C}$ isotope. Mar Biol 73:31-36. https://doi.org/10.1007/BF00396282

30. Shiomoto A, Ishida Y, Tamaki M, Yamanaka Y (1998) Primary production and chlorophyll $a$ in the northwestern Pacific Ocean in summer. J Geophys Res 103:24651-34661

31. Falkowski PG (1981) Light-shade adaptation and assimilation numbers. J Plankton Res 3:203-216. https://doi.org/10.1093/ plankt/3.2.203

32. Parsons TR, Takahashi M, Hargrave B (1984) Biological Oceanographic Processes, 3rd edn. Pergamon Press, Oxford, p 330

33. Chisholm SW (1992) Phytoplankton size. In: Falkowski PG, Woodhead AD (eds) Primary Productivity and Biochemical Cycles in the Sea. Plenum Press, New York, pp 213-237

34. Malone TC (1971) The relative importance of nannoplankton and netplankton as primary producers in the California Current system. Fish Bull US 69:799-820

35. Malone TC, Neale PJ (1981) Parameters of light-dependent photosynthesis for phytoplankton size fractions in temperate estuarine and coastal environments. Mar Biol 61:289-297. https ://doi.org/10.1007/BF00401568

36. Sarthou G, Timmermans KR, Blain S, Tréguer P (2005) Growth physiology and fate of diatoms in the ocean: a review. J Sea Res 53:25-42. https://doi.org/10.1016/j.seres.2004.01.007

37. Williams RB (1964) Division rates of salt marsh diatoms in relation to salinity and cell size. Ecology 45:877-880. https://doi. org/10.2307/1934940

38. Chen B, Liu H (2010) Relationships between phytoplankton growth and cell size in surface oceans: Interactive effects of temperature, nutrients, and grazing. Limnol Oceanogr 55:965-972. https://doi.org/10.4319/lo.2010.55.3.965

39. López-Sandoval DC, Rodríguez-Ramos T, Cermeño P, Sobrio C, Marañón E (2014) Photosynthesis and respiration in marine phytoplankton: Relationship with cell size, taxonomic affiliation, and growth phase. J Exp Mar Biol Ecol 457:151-159. https://doi. org/10.1016/j.jembe.2014.04.013

40. Marañón E, Cermeño $P$, López-Sandoval DC, Rodriguez-Ramos T, Sobrino C, Huete-Ortega M, Blasco JM, Rodríguez J (2013) Unimodal size scaling of phytoplankton growth and the size dependence of nutrient uptake and use. Ecol Lett 16:371-379. https://doi.org/10.1111/ele.12052

41. Sal S, Alonso-Sáez L, Bueno J, Garcia FC, López-Urrutia Á (2015) Thermal adaptation, phylogeny, and the unimodal size scaling of marine phytoplankton growth. Limnol Oceanogr 60:12121221. https://doi.org/10.1002/Ino.10094

42. Shiomoto A, Kawaguchi S, Imai K, Tsuruga Y (1998) Chla-specific productivity of picophytoplankton not higher than that of larger phytoplankton off the South Shetland Islands in summer. Polar Biol 19:361-364 
43. Shiomoto A, Tadokoro K, Monaka K, Nanba M (1997) Productivity of picoplankton compared with that of larger phytoplankton in the subarctic region. J Plankton Res 19:907-916. https://doi. org/10.1093/pankt/19.77.907

44. Sommer U (1989) Maximal growth rates of Antarctic phytoplankton: only weak dependence on cell size. Limnol Oceanogr 34:1109-1112

45. Menden-Deuer S, Lessard EJ (2000) Carbon o volume relationships for dinoflagellates, diatoms, and other protist plankton. Limnol Oceanogr 45:569-579. https://doi.org/10.4319/ lo.2000.45.3.0569

46. Montagnes DJS, Bergers JA, Harrison PJ, Taylor FJR (1994) Estimating carbon, nitrogen, protein, and chlorophyll $a$ from volume in marine phytoplankton. Limnol Oceanogr 39:1044-1060. https://doi.org/10.4319/lo.1994.39.5.1044

47. Strathman RR (1967) Estimating the organic carbon content of phytoplankton from cell volume or plasma volume. Limnol Oceanogr 12:411-418. https://doi.org/10.4319/ lo.1967.12.3.0411

48. Legendre $L$ (1990) The significance of microalgal blooms for fishes and for the export of particulate organic carbon in oceans. J Plankton Res 12:681-699. https://doi.org/10.1093/ plankt/12.4.681

49. Sommer U, Charalampous E, Genttsaris S, Moustaka-Gouni M (2017) Benefits, costs and taxonomic distribution of marine phytoplankton body size. J Plankton Res 39:494-508. https:// doi.org/10.1093/plankt/fbw071

50. Kitamura $M$, Nakagawa $Y$, Nishino $Y$, Segawa $S$, Shiomoto $A$ (2018) Comparison of the seasonal variability in abundance of the copepod Pseudocalanus newmani in Lagoon Notoro-ko and a coastal area of southwestern Okhotsk Sea. Polar Sci 15:62-74. https://doi.org/10.1016/j.polar.2017.12.004

51. Nakagawa Y, Kitamura M, Nishino Y, Shiomoto A (2016) Community structure of copepods associated with water mass replacement in the coastal area of the southwestern Okhotsk Sea during ice-free period. Bull Soc Sea Water Sci Jpn 70:49-50
52. Ishizu M, Kitade Y, Matsuyama M (2006) Formation mechanism of the cold-water belt formed off the Soya Warm Current. J Oceanogr 62:457-471

53. Ishizu M, Kitade Y, Matsuyama M (2008) Characteristics of the cold-water belt formed off the Soya Warm Current. J Geophys Res 113:C12010. https://doi.org/10.1029/2008JC004786

54. Mitsudera $\mathrm{H}$, Uchimoto $\mathrm{K}$, Nakamura $\mathrm{T}$ (2011) Rotating stratified barotropic flow over topography: Mechanisms of the cold belt formation off the Soya Warm Current along the northeastern coast of Hokkaido. J Phys Oceanogr 41:2120-2136. https://doi. org/10.1175/2011JPO4598.1

55. Mustapha MA, Sei-Ichi S, Liha T (2009) Satellite-measured seasonal variations in primary production in the scallop-farming region of the Okhotsk Sea. ICES J Mar Sci 66:1557-1569. https ://doi.org/10.1093/icesjms/fsp142

56. Rose JR, Caron DA (2007) Does low temperature constrain the growth rates of heterotrophic protists? Evidence and implications for algal blooms in cold waters. Limnol Oceanogr 52:886895. https://doi.org/10.4319/lo.2007.52.2.0886

57. Nakagawa Y, Kitamura M, Shiomoto A (2016) Feeding Rates of Dominant Copepods on Phytoplankton in the Coastal Area of the Southwestern Okhotsk Sea. Transactions on Science and Technology 3:439-443

58. Odate T, Imai K (2003) Seasonal variation in chlorophyll-specific growth and microzooplankton grazing of phytoplankton in Japanese coastal water. J Plankton Res 25:1497-1505. https://doi. org/10.1093/plankt/fbg110

Publisher's Note Springer Nature remains neutral with regard to jurisdictional claims in published maps and institutional affiliations. 